\title{
Feyzi Halıcı Şiirinin Tasavvuf Bağlamında İncelenmesi
}

\author{
Dr. Ahmet Karakuş \\ Atatürk Üniversitesi, Ata-Tömer \\ ahmet.karakus@atauni.edu.tr
}

Öz

İslam'ın muhabbete ve aşka dayalı hikemî, ahlaki ve irfani tarafı olarak da tanımlanabilecek tasavvuf, Türk şiirinin birçok evresinde şairler tarafından işlenmiş bir temadır. Modern dönem şairleri arasında da ele alınan tasavvuf, çeşitli istılahlar dikkate alınarak Âşıłk Fezaî mahlasıyla da bilinen Feyzi Halıcı şiirinde de yer almıştır. Manzum ve mensur, kafiyeli ve serbest tarzda şiirleri olan Feyzi Halıcı herhangi bir tarikata intisabı olmasa da Hz. Mevlânâ ve Mevlevilikten etkilenip tasavvufu şiirinde işleyen çağdaş Türk şairlerindendir. Halıcı şiiri tasavvufi ıstılahlar dikkate alınarak ele alınmıştır. Feyzi Halıcı şiirinde özellikle Hz. Mevlânâ, Yunus Emre, Ahmed Yesevî ve Mevlevi postnişinlerinden Şeyh Galip, çalışmanın tasavvuf büyükleri adındaki alt başlığında verilmiştir. Ayrıca tasavvufta önemli istılahlardan olan mürşit ve mürit başlıklarında şeyhlik ve dervişlik ele alınmıştır. Zikir başlığında ise sema'nın şiirde nasıl geçtiği verilmeye çalışılmış, ney ve kudüm gibi Mevlevi zikrinin önemli müzik aletleri Mevlevi enstrümanlar maddesinde işlenmiştir. Tasavvuf için bir başka önemi olan tecelli kavramının yanında nefs istılahı da diğer başlıklar olarak verilmiştir. Tasavvufta sülukun nihayeti için dervişin hâli olan aşk ele alınmış, varlık-yokluk kavramlarının Halııı şiirinde nasıl ele alındığı işlenmiştir.

Anahtar Kelimeler: Mevlevilik, tasavvuf, 1stılah, şiir, etki.

\section{The Examination of Feyzi Halici's Poetry in the Context of Sufism}

\section{Abstract}

Sufism, which can be defined as the historical, moral and wise side of Islam based on love and affection, is a theme treated by poets in many phases of Turkish poetry. Sufism, also treated among modern period poets, has been included in Feyzi Halıcı's poetry, also known as Âşık Fezaî, by considering various terms. Feyzi Halıcı has poems in verse and prose, rhyme and free style and is not affiliated with any sect, but he is one of the contemporary Turkish poets influenced by Hz. Mevlana and Mevleviyeh and treated Sufism in his poetry. Halıcı's poetry was studied by considering sufistic terms. In his poetry, especially Hz. Mevlânâ, Yunus Emre, Ahmed Yesevî and Şeyh Galip one of the sheiks of Mevlevi, were given under the subtitle of the study named as Sufism elders. Also, sheikhdom and dervishhood were discussed in murshid and disciples title, which are among the important terms in Sufism. In the title of dhikr, it was tried to explain how the sema was mentioned in poetry, and important musical instruments of the Mevlevi dhikr like ney and kudum were mentioned in the Mevlevi instruments item. Besides manifestation notion, especially important for Sufism, the nafs term was also treated as other titles. In Sufism, love, as the state of dervish for the end of the süluk (spiritual travelling) was discussed and how presence-absence notions are handled in Halıcı's poetry was treated.

Keywords: Mevleviyeh, sufism, term, poetry, effect. 


\section{GİRIŞ}

Dünya genelinde müntesipleri bulunan ve içtimai bir kurum olan tasavvuf, 'sufilerin mutlak hakikate ulaşmak için aldıkları gönül terbiyesi' olarak ifade edilebilir. Nefahât'a göre sufi ifadesi ilk olarak Süfyân-1 Sevrî'nin çağdaşı Ebû-Hâşim-i Kûfî́ye söylenmiştir (Gölpınarlı, 2004, s. 20). Ayrıca Süleyman Uludağ, tasavvuf ve sufiyye deyimlerinin ilk defa Sünniler tarafından kullanıldığını, Mustafa Kara'nın "Din Hayat Sanat Açısından Tekkeler ve Zâviyeler" adlı kitabının "Tasavvuf ve 'Tekkeler ve Zaviyeler' Hakkında" şeklindeki tasavvufla ilgili fikirlerini verdiği kısımda (bk. Kara, 2015, s. 13-37) belirtmiştir (Kara, 2015, s. 30).

Bilindiği üzere tasavvuf anlayışında mürşit, mürit, ihvan gibi kavramlar temel 1stılahlardandır. Uludağ yukarıda belirtilen yazısında sufilerin piri ve tasavvufun ilk şeyhini, tabir yerindeyse vurgusuyla Hz. Peygamber olarak vermektedir (Kara, 2015, s. 24). $\mathrm{Bu}$ ifade sufilerin yolunun kitap ve sünnet olduğunu göstermektedir. "İşte tasavvuf dediğimiz, mistik birtakım teoriler temelinde gelişen asıl sufilik akımı ise Abbasilerin ilk yüz yılını takiben bu altyapı üstünde eski İslam öncesi çevre mistik kültürlerle temas sonucu, çok tabii bir şekilde kendiliğinden oluşan bir sentez olarak doğdu" (Ocak, 2016, s. 173-174). Bu, tasavvufun kendisinden önce veya bulunduğu dönemde etkilenmelere maruz kaldığını vermektedir. Bu etkilenmenin sıhhatli oluşu, genel anlamda tasavvufun, özel anlamda ise intisap edilen tarikatın şeri bağlamda kıyası yapılarak kontrol edilebilir. Çünkü asıl öz ve çekirdek İslam'dır.

$$
\begin{aligned}
& \text { Tasavvuf haddi zatında, kendi kültürleri üzerine -dışarıdan, üstelik 'medeniyetçe daha } \\
& \text { aşağı' seviyedeki-gözüpek bedevi Arap fatihleri sayesinde hâkimiyet kuran İslam'ın tevhit } \\
& \text { inancını fazla yalın ve açık bulan köklü ve yerleşik 'üstün' bir kültürün mensuplarının, } \\
& \text { bu kültürü galiplerin inancının kalıplarını kullanmak suretiyle o inanç içerisinde tekrar } \\
& \text { diriltme, yaşatabilme ve koruyabilme çabası olarak, İslam'ın içinde âdeta 'paralel bir din' } \\
& \text { şeklinde algılanabilir (Ocak, 2016, s. 176). }
\end{aligned}
$$

Burada Ocak'ın kullandığı "paralel din" tabiri veya yorumu yine Ocak'ın "İslam'ın içinde" vurgusundan dolayı tasavvufun İslam ile alakalı bir kurum olduğunu vermektedir. Aksi düşünce yani tasavvufu farklı bir inanç şeklinde görme ise ayet-i kerimenin uyarısını hatırlatmaktadır. Âl-i İmrân Suresi 19. ayet-i kerime olan bu ilahi sözlerde Allah Teala din olarak sadece İslam'ı göstermektedir (Karaman vd., 2015, s. 50). İnananlar için bu emir ise tasavvufun İslam'dan farklı bir çizgide olmamasını işaret etmektedir. Bu işaret, tasavvuf ehli şairlerin de şiirlerini İslami bakış açısıyla yazmaları gerektiğine dinî bir dayanak olarak görülebilir.

Herhangi bir tarikat müntesibi olup şiiri hikmetli söz düşüncesiyle değerlendiren birçok meşhur şairin olduğu bilinmektedir. Bu bağlamda bu şairlerin şiirleri, dinî tasavvufi olarak sınıflandırılabileceği gibi edebî bir vaaz olarak da düşünülebilir. Mistiklik kavramını dört gruba ayıran ve üçüncü grubu sanatkâr mistisizmi olarak ele alan Hilmi Ziya Ülken, bu kavramın sembolik dille belirtilen mistik tecrübeyi verdiğini ifade eder ve bu hususu aynı grup içinde değerlendirir. Alman bediiyatçıların bu durumu manevi hulul olarak isimlendirdiklerini de söyleyen Ülken, ayrıca eski ozanlardan başlayıp Hz. Mevlânâ ve Yunus Emre'ye değin bir kısım Türk mistiğini ise bu grup içinde ele alır (Ülken, 2017, s. 317). Ülken'in vurguladığı tasavvufun bu büyükleri Türk şiirinin birçok safhasında ve dalında olduğu gibi modern Türk şairleri tarafından da gerek pir kabul edilerek gerek etkilenilen örnek şahsiyetler olarak kullanılmıştır. 
Osmanlı döneminde saray sınıfı ve yüksek zümreye ait aristokrat bir tarikat durumuna gelen Mevlevilik (Ülken, 2017, s. 437) çağdaş Türk şiiri içinde de yer almıştır. Yeni Türk şiirinde özellikle de Cumhuriyet sonrasında Mevleviliğin önemli bir yerinin olmasının bir sebebi olarak bu tarikatın gerek basılı kaynaklarla gerek yapılan çeşitli etkinliklerle daha çok gündemde kalması görülebilir. Şairlerin Mevleviliği, Hz. Mevlânâ'yı ve sözlerini ele alan tasavvufi malzemeyi çokça kullandıkları bilinmektedir. Bu malzemeyi niçin kullandıkları sorusu ise şiirleri çalışılan kişilerin -eğer kayıtlarda varsa- yaşamlarının herhangi bir evresinde tasavvuf erbabıyla hemhâl olup olmadıkları, bir mürşide intisap edip etmedikleri, tasavvuf hakkında bilgilerinin olup olmadığı, yaşadıkları çevrenin bu kuruma olan yaklaşımı gibi hususların incelenmesi sonucunda cevaplanabilir.

Genetik bir yatkınlığın çeşitli dallar vasıtasıyla farklı şekiller hâlinde yansıması olarak düşünülebilecek sanat, yontulup işlenen insanla yapılabilir ve kişinin manen yükselmesiyle kendisinde oluşan latif duygularla beraber hasıl olan incelikler eserlerde görülür (Kılıç, 2013, s. 90). Şiire bu ifadeler bağlamında bakıldığı zaman tasavvufu ele alan şairlerin de bu zerafette olmaları gerekliliği ortaya çıkmaktadır. Feyzi Halıcı'nın hayatı incelendiği ve şiiri değerlendirildiğinde ise şairin şiiri ve tasavvuf arasındaki bağ görülecektir.

\section{Feyzi Halıcı Şiiri ve Tasavvuf}

Tasavvufun Türk toplumunda önemli bir yerinin olması, dinin Türk toplumu içinde değerli olmasındandır. Kutsala olan bağlılıktan dolayı Türkler arasında din adamlarına olan saygının hiçbir zaman eksilmediği bilinmektedir. Bu hürmet, manevi hâllerinden dolayı dervişlere de teşmil edilebilir. Ancak zamanla tekkeler cehaletin yeri olduğu gibi önceden tertemiz olan tekke mimarisi de harabeye döndü. İlkin insana inşirah eden dervişler artık kasvet vermeye başladı. Halefler seleflerinin bıraktıklarını koruyamadı; dergâhlar virane hâline geldi. Cumhuriyet hatta Tanzimat ve Meşrutiyet dönemi insanları tekkeyi bu şekilde görünce tasavvufu reddettiler. Ecdadından utanan bu nesil suni ecdat buldu ve bu onları tatmin etmedi. Bu insanlar, İslam'a zit ideolojilerden medet umdular ama umdukların bulamadılar ve buhrana düştüler (Kara, 2015, s. 34-35). Fakat bu huzursuz ortamla beraber Cumhuriyet döneminde birçok şair tarafından tasavvuf içerikli şiirlerin yazıldığı da bilinmektedir. Bu şairlerden biri de 1924 yılında Konya'da doğan ve burada Çağrı Dergisi'ni çıkaran ayrıca Fezaî mahlasını kullanarak saz şairleri tarzında da yazan Feyzi Halıcı'dır (Necatigil, 2007, s. 213). Şairlerin herhangi bir temayı şiirlerine yansıtmasının sebeplerinden biri olan etkilenme tasavvuf bağlamında düşünülürse bu, şairin bir tarikata müntesip olmasıyla ilişkili olabildiği gibi iki binli yıllarda bazı çevreler tarafından tasavvufun edebiyat camiasında popüler bir yer kazanması ile de alakalı olabilir. Feyzi Halıcı için düşünüldüğü zaman bu etkilenme, Halıcı'dan aktarılan bilgiye göre şairin Hz. Mevlânâ dergâhının bitişiğinde bulunan Celâl Sokağı'nda yer alan bir evde dünyaya gelmesinin ve yapılan mülakatta ise şairin belirttiği üzere beş-altı yaşlarına kadar bu evde oturmasının (Gönen, 2016, s. 11) çocuk zihninde belirgin bir yer edinmesi şeklinde de tezahür edebilir. Şairin, semazen eğitimi için İstanbul'dan Konya'ya hoca getirmesi ve böylece 18-20 civarında semazen yetiştirmesi hakkında verdiği bilgi (Gönen, 2016, s. 12) ve Halıcı'nın Hz. Mevlânâ ile ilgili anma toplantıları, kongre ve sempozyumlar düzenlemesi (Halıc1, 2005, s. 5) de onun tasavvuftan etkilenip bu içerikte şiirler yazmasına bir başka argüman olarak düşünülebilir. Gönen'in “Âşskların babası, yaşayan âşıkların üstadı, yanmak için çıra arayan çırakların parlamasına vesile olan yol arkadaşı, eski Konya Senatörü, yazar, şair, âşık, şeyhül âşıîn ve reis-ül âşı... vb. daha birçok sözle tavsif edebileceğimiz Feyzi Halıcı 
üstadımızın..."(Gönen, 2016, s. 11) ifadeleriyle tanıttığı Halıcı'nın şairlik ve âşıklık yönünü ön palana çıkararak övgüyle bahseden bu düşünceleri ise yazarın şaire verdiği değeri göstermektedir. Ayrıca Gönen'in “Yine Sayın Halıcı'ya, derginin adını neden Çağrı olarak verdiğini sorduğumuzda: Hz. Mevlânâ'ya atfedilen 'Ne olursan ol yine gel' çağrısından hareketle derginin adını Çağrı olarak vermeyi uygun bulduğunu söylemiştir" (Gönen, 2016, s. 14) şeklindeki görüşmesi, Halıcı'nın Hz. Mevlânâ sevgisiyle ne kadar ince düşündüğünü gösteren bir diğer argüman olarak görülebilir. Yazar, "Feyzi Halıcı her şeyden önce şairdir, âşıktır. O aslında şiire başlamasını Hz. Mevlânâ yakınında bulunmasına bağlamış..."(Gönen, 2016, 15) sözlerinde de yine Halıcı'nın âşıklığına vurgu yapmakta, şiirinin temelinin de Hz. Mevlânâ'yla yani tasavvufi hâl veya düşünceyle bağlantılı olduğunu vermektedir. $\mathrm{Bu}$ ifadelerin geneline bakıldığı zaman $\mathrm{Halıc1}$ için tasavvufun/Mevleviliğin şiirden öte âdeta bir yaşam biçimi olduğu da söylenebilir. Halıcı'da etkisi belirgin olarak görülen Mevlânâ'dan Abdurrahim Merzifonî Zeyneddin-i Hafî̀nin halifesi olan ve bugün için bilinen en eski Mesnevi şerhini yapan Mustafa Muinî, Mesnevi etkisiyle Ney-nâme, Miskin-nâme gibi eserler yazan Halveti Dede Ömer Ruşeni, Hz. Şârih unvanını alan ve önceden Bayrami tarikatına bağlı iken daha sonra Mevlânâ hayranlığından dolayı Mevleviliğe intisap eden Ankaralı İsmail Rüsûhî Dede, Celveti olan ve Rûhü'lMesnevî şârihi Bursalı İbrahim Hakkı Efendi, Halveti tarikatının Gülşeni kolunun kurucusu olan ve Mesnevi etkisiyle Ma'nevî adlı eseri yazan İbrahim Gülşenî gibi feyz alan ve Mevlânâ'nın tarikatlar üstü bir şahsiyet olduğunu veren daha birçok örnek bulunmaktadır (Mazıoğlu, 1981, s. 31-32). Günümüzde de -genelleme yapılmadan söylenirse- ayin ismiyle de olsa salt foklorik malzeme yapılan sema'nın çeşitli vesilelerle aşikâr bir şekilde sunulması, bilindiği gibi bu ayinde müziğe yer verilmesi ayrıca bu sunumlarda görülen tarikat kıyafetlerinin ve ritüellerinin günlük yaşamdan farklı olması zikri/sema'yı/gösteriyi/töreni dikkat çekici hâle getirmektedir. Bu hususlardan dolayı da halk arasında ve sanat çevrelerinde Hz. Mevlânâ'nın tanınan bir mutasavvıf ve Mevleviliğin ise bilinen bir tarikat olarak görüldügü söylenebilir. Bu durumun Cumhuriyet dönemi şairleri için de geçerli olduğu ifade edilebilir. Son dönem şairlerinden olan Halıcı'nın da "Aşk dedik düştük yola! Güç ve kuvvet dileğimiz, kainatın yaratıcısı Cenab-ı Hak'tan, destur ve ilham, efendimiz Mevlânâ'dan" (Halıcı, 1981, s. 42) ünlemesi, özellikle de "destur" nidası ve bağlılığını vurgulayan "efendimiz" şeklindeki aitlik sözcüğü, şairin Hz. Mevlânâ müntesibi olduğunu düşündürmektedir. Ancak incelediğimiz ilgili kitaplarda Halıcı'nın herhangi bir tarikata bağlı olduğu ibaresinin geçmemesi ve özellikle kız kardeşi Nevin Halıcı tarafından şairin derin bir tasavvuf bilgisi olduğunun fakat herhangi bir tasavvuf yoluna intisabının bulunmadığının bildirilmesi (N. Halıcı, kişisel iletişim, 13 Ağustos 2020) Feyzi Halıcı'nın müntesip olmadığını açklamakta ve bu bilgiler şairin -“...destur ve ilham, efendimiz Mevlânâ'dan" (Halıcı, 1981, s. 42) ifadesinden de anlaşıldığı gibi- bir derviş misali Hz. Mevlânâ'ya hürmet ettiğine dair bir başka dayanak olarak da görülebilir. Halıcı'nın bazı şiirlerini İtalyanca'ya çeviren Anna Masala'nın (bk. Masala, 1987, s. 33-132) şair hakkındaki "Mevlânâ aşkı sayesinde, şair Halıcı kendi insancıl ve sanatsal yolunu bulmaktadır" (Masala, 1987, s. 14) yargısı bize bir yabancının gözünden şairin tasavvuftan etkilenmesini vermektedir. Ayrıca

[...]değişik bir fikir, duygu ve vezin yapısı içinde Feyzi Halıcı'nın şiirini programl bir manifesto içinde hangi akım diye adlandırmak olanaksızdır. Halıcı'yı bir halk şairi olarak tanıtmak yargısı şu an için acele verilmişs sayılacă̆ı 
gibi onu bir mistik şair addetmek de büyük bir eksiklik meydana getirir (Masala, 1987 , s. 16).

şeklindeki ifadeleri ile Masala, şairi sadece bir grupta veya bir adlandırmanın içinde görmediğini ve onun şiirini geniş bir çerçevede değerlendirmek gerektiğini vurgulamakta bu da yazarın Halıcı'yı büyük şair sınıfına koyma gayretinde olduğunu göstermektedir. Bu, Masala'nın şaire verdiği değerin belirtisidir. Ayrıca bu ifadeler, yazar için Feyzi Halıcı'nın belli bir seviyenin üstünde olan bir sanatçı, birçok tarzı şiirinde barındıran üst düzey bir şair olduğunu da vermektedir. Bu bağlamda düşünüldüğü zaman şairin bu çalışmada ele alınan şiirlerinde şeklî açıdan beyit, dörtlük, beşlik gibi formların; kafiyeli, serbest ve mensur şekilde çeşitliliğin de fark edildiği gibi şairde duygu bakımından derviş edasının varlığının da yadsınamayacağı görülmektedir. Bu formlar sadece nazım birimi olarak kullanılmamış, şair bu farklılıklarla tasavvufu değişik tarzlarda da kullanma imkânı bulmuştur. Bu imkânla Halıcı, tasavvufi duygularını bir taraftan kafiyelerle, âşık tarzında yazarak karşısında bir dinleyici topluluğu varmışçasına onlara duyurmak ister gibidir. Ayrıca serbest şiirin okuyucuya verdiği kalıplara bağımlı olmama hissi ile şairin tasavvufu rahat bir tonla aktarma gayretinde olduğu da düşünülebilir. Halıcı'nın mensur şiirdeki hem kafiyenin verdiği melodi ile hem de nesrin sohbet havası katan anlatımıyla ise bu sufi düşünceyi okuyucusuna/dinleyicisine huzurlu bir ruh hâliyle de ifade etmek istediği akla gelmektedir. Bu husus, şekil ve muhteva arasında bir bağ olarak görülebileceği gibi şairin hangi tarzda olursa olsun tasavvufun, şiirinin vazgeçilmez bir teması olduğunu da vermektedir.

\section{Tasavvufi Terminoloji Bakımından Şiirlerde Geçen Belirgin Unsurlar Tasavvuf Büyükleri}

Feyzi Halıcı şiirinde özellikle Hz. Mevlânâ olmak üzere Yunus Emre ve Ahmed Yesevî́nin de varlığı belirgin olarak görülmektedir. Birçok eserinde şair, bu tasavvuf büyüklerinden bahsetmektedir. Ayrıca bir Mevlevi büyüğü olan Şeyh Galip de Halıcı şiirinde yer almaktadır.

Halk içinde din ve tasavvuf büyüklerinin vesile kılınarak onların hürmetine Allah Teala' dan bir şeyler istenerek dua edildiği bilinmektedir. Halıcı'nın "Sitem" adlı şiirinde Hz. Mevlânâ, vesile yapılarak şiire girmiştir:

“Tez elden dilerim, bitsin bu acı,

Dost mektuplarıdır derdin ilâcı.

Mevlâna katında oldum duacı,

Huzuruna mahcup gelmedim Kardaş..." (Âşı1k Fezaî, 1998, s. 80).

Şairin tasavvufi aşkı ele aldığı "Hak Aşıklarına" adlı 11'li şiir ölçüsüyle yazılan âşık tarzı şiirinin ilk dörtlüğü olan

“Bereketin bol olduğu yerdeniz,

Aşkın anahtarı elimiz bizim.

Yunus Emrelerden hak âşıklara

Nağmeler iletir, dilimiz bizim..." (Âşık Fezaî, 1998, s. 81).

dizelerinde ise Halıcı'nın şiirinde Hz. Mevlânâ'dan sonra en fazla dile gelen Hak dostu Yunus Emre verildiği gibi "hak âşılara" ifadesiyle ise ehl-i tasavvuf işlenmiştir. Ayrıca "Bereketin bol olduğu yerdeniz," mısrasının tasavvufun manevi etkisini verdiğini 
söylemek gerekir. Buradaki "bereket" ifadesi tasavvuf ıstılahlarından olan feyz ve muhabbet olarak da düşünülebilir.

Halıcı'nın “Dörtleme'ler-Şiirler (II)" kitabında verdiği şu bilgilere değinmek gerekir:

Dörtlemeler, yazılmış şïrler değildir. Hepsi de söylenmiş şiirlerdir. Dörtlemeler'in kökeninde Orhun-Yenisey Kitabelerinin ruhu vardır. Bu ruh, Türklerin İslamiyeti kabul edişleriyle büyük bir inançla gelişip, Ahmed Yesevî Hz.nin hikmetlerine gelir dayanır, uzun bir soluk alır. İslamiyetin 'eşref-i mahlukat' olan insana bahşettiği yaşama sevinci, Hak gerçeği ile özdeşleşen insan sevgisinden nasibini alır. Rahman ve Rahim olan Cenab^ Hakk'a ve onun emirlerine tam bir bağgllıkla yoluna devam eder. Dörtlemeler'in manevi gücü ve ilham kaynağı olan Yesevî Hz.nin öğ̈̈tleri, ihlası, hâl ve hareketi Dörtlemeler'de bir nur halesi olarak yansır (Halıc1, t.y., C. 2, s. 3-4).

Aynı eserde verilen "Pîr-i Türkistan" dörtlemesi bu "nur"un sahibine olan muhabbetin şiiridir:

“İki kardeş, biri Anadolu, biri Türkistan,

Yusuf Hemedanî'den beri dipdiri Türkistan,

Sonsuz yaşama sevincidir tekmil insanlığa,

Seven gönüllerin özlemidir, Pîr-i Türkistan." (Halıcı, t.y., C. 2, s. 61).

Feyzi Halıcı'nın şiirinde belirgin olan tasavvufi şahsiyetlerden biri de bir Mevlevi dervişinin oğlu olan Galata Mevlevihanesi postnişini, XVIII. y.y. şairlerinden Şeyh Galip'tir ki şair, III. Selim ve kız kardeşi Beyhan Sultan'ın da iltifatlarına mazhar olmuştur (Necatigil, 2007, s. 397). Bu açılamaların yapılmasının sebebi Halıcı'nın bazı şiirlerinde olduğu gibi "Başlangıç" şiirinde de Şeyh Galip'ten bahsetmesidir. Çünkü şairin mensur şiirlerinden olan "Başlangıç"ta Şeyh Galip ve III. Selim geçmektedir. Ayrıca Şeyh Galip ile şairin divanı'nda dört kaside, beş tarih ve bir terciibent yazdığ 1 Beyhan Sultan arasında bir gönül ilişkisi rivayetinin olması (Ayvazoğlu, 1999, s. 69) bu şiirde geçen "Sûzi Dilâra" tamlamasının Beyhan Sultan için kullanıldığını göstermektedir. Şiirde bir tasavvuf büyügünün maddi aşkı görülmektedir:

Bir bakarsınız, sevgi bir berrak sudur. Bir nota düşer, ilkin bu berrak suya. küçümencik. Daireler büyür büyür. Aksi sedalarda karşınıza Şeyh Galip çıkar, İkbal çıkar. Bir yarı gecede tekmil kulak kesilirsiniz. Üçüncü Selim bütün haşmetiyle size aşkın kılavuzluğunu yapar. Bahtınıza bir Sûzi Dilâra çıkar. (Halıc1, 1964, s. 58).

\section{Mürşit}

Tasavvuf terimleri arasında en temel sstılahlardan biri olan mürşit, saliki sülukunda Hakk'a vasıl eden rüşt sahibi bir rehber, dervişin nefsine galebe çalmasına yardımcı olan bir vesile olarak görülebilir. Hz. Mevlânâ için mürşit ise Şems-i Tebrîzî'dir.

Mevlânâ tarihe baktığında Şems'in kişiliğini, aşă̆ıdaki erdemli yüce zatlara yansıtıyordu: Iffetin sembolü Hz. Yusuf'a, sabrm sembolü Hz. Yakub'a Allah ile konuşan ve sevgisinden dolayı dağı yerinden oynatan Hz. Musa'ya, sevgiyi temsil eden Hz. İsa'ya ve yine aynı şekilde yaratıcı hakikati temsil eden Hz. Muhammed ve Hallâc-ı Mansûr'a. O, yine Şems'i normal dünya [yaşantısı] stilini temsil etmeyen ve hakikat yolunu izleyen Nuh'a, meleklere ve diğer birçok keramet ehline benzetiyordu (Aresteh, 2007, s. 57). 
Bunun en temel sebebinin ise ilahi aşk olduğu söylenebilir. Hz. Mevlânâ için bu aşkın muhatabı olan Şems, Halıcı'nın "Hak Aşıklarına" adlı şiirinin

"Katre katre yola vurduk denizi

Ayırd ettik kusurludan temizi.

Yaktı şavkımızı Şems-i Tebrizi

Mevlâna katında dolumuz bizim." (Âşık Fezaî, 1998, s. 82).

şeklindeki mısralarında verilmektedir. Tasavvuf yolunu anlatan ve tasavvufun dervişe doğruyu bulduran manevi bir yol olduğu vurgusunun yapıldığı bu dizelerde Şems-i Tebrîzî tasavvufi bir aşkla, feyzle ve muhabbetle Hz. Mevlânâ'nın manevi yolu dikkate alınarak verilmiştir ki “Mevlânâ'ya göre aşk, EFLÂTÛN'da olduğu gibi ruhun zihnileşmiş olan bir yükselişi değil fakat Nev-Eflâtûnîlerde olduğu gibi eşya ve kesretle bütün bağlarını keserek insanı birliğe ve bütünlüğe götüren bir istiğrak [anthousiasme] hâlidir" (Çelebi, 1957, s. 51-52). Burada tasavvufun felsefe mi, değil mi? sorusu akla gelmektedir. Bu sorunun yanıtı bu makalenin dışında bir husus olduğundan dolayı cevabı tasavvuf tarihçilerine ve felsefecilere bırakmak gerekir. Ancak istiğrak hâli bilindiği üzere diğer tarikatlarda da olduğu gibi Mevlevilikte de feyz ve muhabbetin, mürşidin nazarının, müridin gayretinin neticesi olarak da ifade edilebilir. Bu hâlin Hz. Mevlânâ'nın hem yaşantısında hem de eserlerinde görüldüğü bilinmektedir; yansıması ise Feyzi Halıcı şiirindedir.

Halıcı'nın mürşit ile alakalı bir başka şiiri ise "Meşk"tir. Tasavvufi aşkı, manevi tadı, tarikat yolunu anlattığı bu şiirde salikin sülukunda ilerleyebilmesi için mürşidine bağlılığının gerekliliği vurgulanmaktadır. Ayrıca Allah Teala'ya vasıl olmak için acı çekmek yani özlem duymak gerektiği de belirtilmektedir. Bunun yanında mürşit vasıtasıyla müridin "elmaya el sürmeyeceği" yani günahlardan alıkoyulacağı da yaratılışa telmih yapılarak bu şiirde verilmektedir:

“Meşk olmaz aşk hırkasını giymeden,

Yol alınmaz ustaya baş eğmeden.

Vuslata özlemle erdim çok şükür,

Bahçede elmaya hiç el değmeden." (Halıcı, t.y., C. [1], s. 30).

\section{Mürit}

Tasavvufta tarikat erbabı için ihvan, derviş, âşık, salik gibi isimlendirmelerin yanında mürit kullanımı da yaygındır. Müridin asli görevi seyr-i sülukunu tamamlamaktır. Dervişin içindeki teşvişi öldürmesi sülukunun akıbeti açısından gayet önemlidir. Gayret ve teslimiyetin olmaması, yahut yeterince olmaması, salikin yolunu tamama erdirememesine sebebiyet verecektir "Şeyhin önündeki mürit gassalın önündeki cenaze gibidir, iradesi yoktur; şeyh ona hangi şekil verirse onu muhafaza eder; şeyhte fâni olmak Allah'ta fâni olmanın mukaddimesidir" (Uludağ, 2005, s. 334). Feyzi Halıcı herhangi bir tarikat kapısına girmemiş olsa da (N. Halıcl, kişisel iletişim, 13 Ağustos 2020) şiirinde belirgin olarak görülen tasavvuf izleğinin içinde müritlik kavramına da yer verdiği görülmektedir. Şair "Aşk" adlı mensur şiirinde "su" ve "kab" ile bir benzetme yaparak hem ilahi aşkı hem de mürşit ve müridin manevi hâlini anlatmaktadır:

Aklın bittiği nokta, gerçek aşkın başlangıç noktasıydı. Akıl suyun, içine boşaltıldığı bir kabın şeklini almasın emrediyor, aşk, suya göre kabın şekil değiştirmesini zorunlu 
kılıyordu. İlâhi aşkta teferruat yoktu, şekil yoktu, sebep yoktu, bir yalınca sonuç vardı o kadar. (Halıcı, 1964, s. 32).

Şiirde tasavvuf yolunda aklın değil, aşkın önemli olduğu vurgulanmaktadır. Fakat bu, tasavvufun aklı kabul etmediği anlamına gelmemelidir. Çünkü tasavvuf ehlinin de tabi olduğu Kur'ân-1 Kerîm'de akıl vurgusu yapılmaktadır: “De ki: Pis ve kötü ile temiz ve iyi bir değildir; pis ve kötünün çokluğu tuhafına gitse (yahut hoşuna gitse) de (bu böyledir). Öyleyse ey akıl sahipleri! Allah'tan korkunuz ki kurtuluşa eresiniz" (Karaman vd., 2015, s. 117) şeklinde verilen Mâide Suresinin 100. ayeti bu hususa bir örnektir.

Tasavvufta dervişin bağllı̆̆ının önemi ve müridin şeyhinin ilim, hilm, fehm gibi hasletlerini elde etmek için çabalaması gerektiği bilinmektedir. "Aşk" şiirinde Halıcı'nın, mürşidi "su" ve müridi "kab" şeklinde benzetmesi bu gerekliliktendir. Ayrıca "Aşk"ta tasavvuf için önemli bir kazanım olan müridin mürşidine teslimiyetinin olması verilmekte, özellikle de dervişin, şeyhinin teslimiyetini kazanması gerekliliği vurgulanmaktadır. Şairin bir başka şiiri olan "İstanbul Caddesi- Günaydın"ın şu dizelerinde ise "...ilk mevlevî"den bahsedilmektedir:

“ilk musiki, ilk makam, öyle uhrevî

İlk hasretin gönüllerde ilk alevi.

Rüzgâr rüzgâr tennûrede ilk mevlevî

Günaydın!." (Halıcı, 1983, s. 208).

Şiirde "...ilk mevlevî" denilerek Hz. Mevlânâ kastedilebileceği gibi musahibi Şems-i Tebrîzî de verilmiş olabilir. Bazı tarikatların zikir meclislerinde giydikleri kendilerine has kıyafetleri vardır. Bilindiği gibi tennure de Mevlevilerin sema elbisesidir. Bu şiirde görüldüğü üzere müritlik 1stılahının yanında tarikat giysisi, Mevlevi musikisi, "hasret" kelimesiyle müridin mürşidine yahut mürşidin Cenab-1 Hakk'a özlemi ve "alev" sözcüğüyle ise manevi aşk anlatılmıştır. Halıcı'nın bir başka mensur şiiri olan "Bir Bir Daha" da da müritlik ve mürşitlik verilmekte, mürit naz ile mürşidinden tasarruf beklemektedir. Şiirde "nefes" kelimesi kullanılarak müridin manen varlığının mürşitte olduğu vurgusu yapılmaktadır. Ayrıca bu şiirde de "tennûre" verilmiş, bu kelimenin yanında "pervane" sözcüğünün kullanımıyla da buradaki mürit ve mürşitliğin Mevleviliğe ait olduğu anlaşılmaktadır:

Avcumdasın dudağımdasın. Yönümdesin, yöremdesin. Can körüğüm benim, üfle beni, nefes ver bana! Bir pervaneyim tennûrenin içinde. Vişne reçeli gibi sıcacık, duyuyor musun beni? Hep öyle dur, hep öyle kal! (Halıc1, 1998, s. 58).

Halıcı, "Dörtlemeler"i hakkında şu açıklamayı yaparak tasavvufa meylini göstermektedir:

Kılavuzlarım, asırlar mısralarılla, sağlam ve samimi düşünceleriyle kucaklayan iki gönül şairi Mevlânâ ve Yunus Emre oldu. Beş yaşımdan itibaren Konya ve gönül coğrafyasında şiirleriyle, nağmeleriyle, sohbetleriyle onların karncası oldum. Hep onları dinledim. Onlarm himmetleriyle bu şiiri söylerken zorlanmadım diyebilirim (Halıc1, 2005, s. 16).

Şair, dörtlemelerinden olan "Dişe Diş" şiirinde de Mevlevi müritliğinden bahsetmektedir: 
“Yazmaz bizim defterimiz dişe diş,

Düşünmek ayrı şey, yapmak ayrı iş.

Şükür Mevlâna'nın karıncasıyız.

Gönlümüz Konya ovasınca geniş." (Halıcı, t.y., C. [1], s. 76).

Dörtlükte geçen "karınca" sözcüğüyle müridin gayretli olması gerektiği vurgusu yapıldığı gibi dervişlik tevazusu da işlenmektedir.

\section{Zikir}

Tasavvufi hayatta dervişin vazifelerinden biri de kendi virdinin yanında haftanın belirlenen bir günü yahut günlerinde ihvanlarla dergâhta toplanıp Allah Teala'yı anmak olan zikir çekmektir. Zikir; mürşidin bulunduğu yerde mürşit tarafından, mürşidin olmadı̆̆ şehir, ilçe ya da mahallelerde ise mürşidin görevlendirdiği ve tarikatlara göre zakir, zakirbaşı, çavuş, vekil gibi isimlendirme yapılan görevliler tarafından yaptırılmaktadır. Ayrıca zikrin ayakta veya oturarak ya da Mevlevilerde olduğu gibi sema biçiminde yapıldı̆̆ı bilinmektedir. "Meşrep farkı sebebiyle kimi sufiler cehri/sesli, kimileri de hafi/sessiz zikri tercih etmişlerdir" (Uludağ, 2014, s. 54).

Tasavvufun belirgin bir şekilde görüldüğü Halıcı şiirinde ise Mevlevilik etkisi buna bağlı olarak da sema hâli işlenmektedir.

Sema'nın bütün hareketleri tasavvufi birer semboldürler: Çark atarak sema tevhide
işarettir. Sıçramak ulvi âleme ulaşmak şevkinin sonsuz dereceye geldiğine işarettir. Ayak
vurmak nefsini öldürmeye delalet eder. Kol açmak, vahdete ulaşmaktan dolayı sürurunu
göstermektir. Să̆ elin avucunun yukarıya açık oluşu feyz-i akdes'e işarettir. Să̆ el bu
feyzi yukarıdan alır, sol el de aşă̆̆ya yani nâsût âlemine verir (Çelebi, 1957, s. 53).

Mevlevilik ve sema denildiği zaman zihinlere Mevlevi dervişinin dönüşü yansımakta, ney, rebab, kudüm gibi sazlar eşliğinde icra edilen tasavvuf musikisi akla gelmektedir. Musiki konusunda mutasavvıflar ve müteşerriler arasında helal olup olmadığı ihtilafı basit olmayıp musikinin Allah'a yaklaştıran, nefsi tehzib, ruhu tezkiye, kalbi tasfiye, insanı terbiye edici olup olmaması şeklindedir. Aslında bu husus musikinin kişiyi Allah'a yaklaştıran ibadet ve taat olup olmama durumudur. Genel anlamda fakih ve muhaddisler, musikinin bu yönünü reddetmiş, mutasavvıflar ise kabul etmişlerdir. Bir taraftan fikıhla da meşgul olan Gazzâlî gibi mutasavvıflar tasavvufun görüşünü kabul ederken bir taraftan da İbn Cevzî ve İbn Kayyım gibi sufi yaşantıları da olan fakih ve muhaddislerin ise müteşerrilerin fikirlerini tercih ettikleri ifade edilebilir (Uludağ, 2017, s. 197).

Halıcı'nın “Gelmedin” şiiri okunduğu zaman ilk iki dörtlükte aşk, dünyevi bir meyil gibi görünmektedir (Âşık Fezaî, 1998, s. 26). Ancak mürşide muhabbetin, aşkın, ilahi yolun, bu yola talip olmanın ve zikrin yani sema'nın verildiği üçüncü dörtlükte Hz. Mevlânâ'nın yer alması bu aşkın uhrevi olduğunu vermektedir:

“Aşk burcu yüce Mevlâna,

Yol açık talip olana.

Aşk içre döne dolana

Gelmedin niçin gelmedin?" (Âşık Fezaî, 1998, s. 26).

Dörtlüğün üçüncü dizesinde yer alan "döne dolana" ifadesi, hem aşkın insanı divane edip etrafı kayıtsızca dolaşması hem de dervişin sema etmesi şeklinde tevriyeli 
kullanılmakta ve Mevleviliğin zikrini akla getirmektedir. Sema, Halıcı'nın "Rüzgâr Değirmeni" adlı şiirinde de ele alınmaktadır. Bu şiirde mananın insan ruhunu temizlemesi, onu güzelleştirmesi vurgulanmakta, Şems ve Mevlânâ'nın muhabbeti verilmekte, bu muhabbet "güneş" ve "pervaneye" benzetilerek ikisi arasındaki hâl anlatılmaktadır. Şiirin ilgili kısmında "Güneş" hem zahirî anlamı ile hem de "Şems"e benzetilişiyle kullanılmaktadır. Coğrafi bir olay olan Dünyanın dönüşü ise sema yapan Mevlevinin tennuresine benzetilmektedir:

Mânâ; insanın, insan ruhunun fethine doğrudur. Güneş ve pervâne, Şems ve Mevlâna. Daire daire mânâ ekseninde bir sonsuz dönüş. Dünya sonsuz bir tennûre. (Halıc1, 1966, s. 52).

Halıcı'nın "Bu mudur?" adlı tasavvufi şiirinde yer alan şu dörtlükte ise zikrin yani sema'nın şeklî tarafı vurgulanarak sema ile Mevlevi dervişinde meydana gelen aşk ve feyz hâli işlenmektedir:

"Bu mu bir mercekten dökülen, nûra,

Bu mu, yedi ufku saran tennûre?

Tanrım, ne mene bir uçan daire

Ateş almış kıpkırmızı, bu mudur?" (Halıcı, 1956, s. 75).

Sema'nın kisvesinin ve şeklinin verildiği bu dörtlükte dikkat çeken bir ifade vardır ki bu "Tanrım" nidasıdır. Halıcı, şair tasarrufuyla tasavvuf ehlinin kullandığı lafzatullah yerine daha çok modern şairlerde ifadesi olan bu yakarışı tercih etmiştir.

Hz. Mevlânâ denildiğinde "Gel" nidası akla gelmektedir. Ancak Yakup Şafak bu rubainin Hz. Mevlânâ'dan ve Baba Efdal'den iki yüzyıl daha öncesinde yaşayan Ebû Saîd'in fikirlerine ve üslubuna daha uygun olduğunu ifade etmekte fakat kaynaklar itibariyle ise rubainin Baba Efdal'e nispetinin daha güçlü olarak göründüğünü söylemektedir. Ayrıca Şafak, bu şiirin Hz. Mevlânâ'ya ait bir rubai olma olasılığını çok zayıf olarak vurgulamakta, eğer güçlü dayanaklar yoksa, rubailerde özellikle mahlasın olmamasından meydana gelen karışıklıktan dolayı bir rubai için mutlaka şu şairindir hükmünün verilemeyeceğini de belirtmektedir (Şafak, 2009, s. 80). Feyzi Halıcı, "Struga Şiirleri III"te bu nidayı vurgulayarak Mevlevi zikrini vermektedir:

“Başliyor çağrısı Mevlâna'nın,

Bembeyaz tennûrelerle.

Alev - yalazı bir sevgiyi

$<<$ Gel >> çağrısına bölerken,

Durmak kolay değil..." (Halıcı, 1983, s. 260).

Şiirde geçen "Alev - yalazı bir sevgiyi" mısrası ile ise şair, tasavvufta önemli olan bir başka hususu; aşk, feyz ve muhabbeti burada da işlemektedir.

\section{Mevlevi Enstrümanlar}

Dinî bakımdan musikinin helal olup olmadığı meselesi İslam âlim, zahit ve sufilerince çokça konuşulmuş ve tartışılmıştır (Uludağ, 2017, s. 196-208). Mevlevilikte sema sırasında bazı entrümanlar kullanılmaktadır. Bu durum tasavvufun farklı bir şeriatta olmasından değildir. Çünkü hiçbir tasavvuf kurumunun İslam hukukunun dışına çıkması akait 
bakımından düşünülemez. Tasavvufun muhabbet üzere kurulu bir anlayış olmasının yanı sıra tasavvufta sadece insanın değil, hayvanların da Allah'ı zikrettiği inancının olduğu da bilinmektedir. Halıcı' nın “Oluş" şirinin

"Ve güvercinlerin çırpınışları,

Bunca yakarışlar sebepsiz değil." (Halıcı, 1964, s. 27).

beytinde de görüldüğü gibi ayrıca halk şiiri tarzında yazılan "Güvercinim" şiirinin

“Öyle garip garip eğme başını,

Sana yaslı durmak suç güvercinim.

Çağır "Hu hu!" diye güzel eşini,

Süzül gökten göğe uç güvercinim!" (Âşık Fezaî, 1998, s. 33).

şeklindeki dizelerinde de verildiği üzere tasavvuftaki hayvanların Allah'ı zikrettiği inancı yer almaktadır. Bu bağlamda düşünüldüğü zaman bir başka husus olan cemadatın zikri de akla gelmektedir. Bunun da tasavvufta inanılan bir husus olduğu bilinmektedir ki "Kâinatı, Allah Teala'nın bir tecellisi olarak gören mutasavvıfların, bütün seslerde bir musiki ahengi görmeleri şaşılacak bir şey değildir; mistisizmin mantığına göre bu çok tabiidir" (Uludağ, 2017, s. 204). Uludağ'ın bu ifadeleri doğrultusunda bakıldığı zaman Mevlevilikte kullanılan estrümanların amacının insanları coşturmak değil, dervişlerin manen feyzini artırmaya vesile olan vasıtalar olduğu inancı ortaya çıkmakta ve bu estrümanların da Yaratıcı'yı zikrettiği düşüncesi doğmaktadır. Mevlevilikte başta ney olmak üzere kudüm ve rebab gibi aletler kullanılmaktadır. Feyzi Halıcı şiirinde de tarikatlar arasında Mevleviliğe hasredilen ney başta olmak üzere bu entrümanların yer aldığı görülmektedir. "Başlangıç" şiiri bunlardan sadece biridir:

"Bir yeşil kubbeden, naylarla, dolu-naylarla, mısra mısra Hz. Mevlâna çıar." (Halıcı, 1964, 58).

"Başlangıç"ın bu bölümünde şair âdeta kelimelerle oynamaktadır. "Nay" ile "dolunay" arasında bağ kurarak bir tevriye sanatı yapmıştır. Şairin "dolu-nay" ile hem ayın en parlak hâli hem de birçok nay anlamındaki kullanımı bilinçli bir tasarrufudur. Bu sanatla Halıcı nay'a bir değer atfetmiştir.

Müslümanlar için dünyada Mekke ve Medine, Katolik Hiristiyanlar için Vatikan, Müslümanlar, Hıristiyanlar ve Museviler için Kudüs, Süryani Hıristiyanlar için Şam ve Mardin gibi bazı şehirlerin, tasavvuf erbabı için ise peygamber kabirlerinin olduğu yerlerin ayrıca tarikat pirlerinin ya da kâmil mürşitlerin hayatta olduğu veya türbelerinin bulunduğu beldelerin kutsiyetinin olduğu bilinmektedir. $\mathrm{Bu}$ bağlamda değerlendirildiği zaman Mevleviler için de Hz. Mevlânâ'nın medfun olduğu Konya, mübarek bir belde olarak ifade edilebilir. Halıcı "Başlangıç" ın yukarıda verilen bölümünde bu öneme vurgu yaptığı gibi şiirin “...mısra mısra Hz. Mevlâna çıkar.” kısmıyla ise Hz. Mevlânâ'nın

“Dinle, bu ney nasıl şikâyet ediyor; ayrılıkları nasıl anlatıyor:

Beni kamışlıktan kestiklerinden beri feryadımla kadın / erkek herkes ağladı." (Mevlânâ, 2013, s. 47). 
mısralarına telmih yapmaktadır. "Başlangıç"1n şu kısmında ise âşı̆̆ın sevgiliye muhabbeti, sevdası ve özlemi Mevlevi entrümanı kudüm, Mevlevi giysisi tennure kişileştirilerek verilmiştir:

“...Bu serince tennurelerin söyleyişidir, canı bedenden esirgemiyen.. Hep hasret içinde kalış. Hep kudüm kudüm özleyiş. Bu yalın zamanlardan nota nota dökülüş.." (Halıcı, 1964 , s. 58).

Burada özellikle "nota nota" ikilemesinin verilmesiyle tasavvuf ve musiki arasında bağ kurulmuştur.

İnsan, yaratılışının gereği olarak dünyada birçok sıkıntıyla karşılaşmaktadır. Hüzün, bireyin hayatı boyunca çokça hissettiği bir duygudur. Müzik ise bu duygunun melodi olmuş hâlidir. Ney de bu duygunun ses hâline dönüşmüş şekli olarak tarif edilebilir. Halıcı, "Siz" adlı şiirinde neyin sesi ile insanın hüzünlü duyguları arasında bir bağ oluşturmaktadır:

"(Burada bir nay sesi, uzunca)

Biraz mendil, biraz aşk, biraz sızı.

İşte benim kurak topraklarım,

Besleyin yalnızlığınızı.." (Halıcı, 1967, s. 26).

Şiirde "uzunca" sıfatının kullanılması bilinçli bir tasarruftur. Neyin sesinin uzunca oluşu ile hüznün devamlı oluşu arasında şair bir ilişki kurmuştur.

\section{Tecelli}

Feyzi Halıcı'nın tasavvuf içeren şiirlerinde şair için bu sufi hayatın ayrı bir yeri olduğu tahlil edilen şiirlerden anlaşılmaktadır. $\mathrm{Bu}$ şiirlerde kullanılan tasavvuf ıstılahlarından biri olan tecellinin Cenab-1 Hakk'ın isim, fiil ve sıfatlarının insana, hayvana, cansız nesnelere, kısacası her yere ve her şeye yansıması ve Allah Teala'nın varlı̆̆ını, yansıma ile delillendirmesi olduğu bilinmektedir. Feyzi Halıcı'nın "Yol" adlı şiirinde verilen bu kavram ya da bu delillendirme bir uyarı ve yergi ile şu dörtlükle ifade edilmektedir:

"Hak gerçeği ayan beyan

Ey dost aydinlığa uyan!

Varlığı pekçe görmeyen

Yokluğa avare gider." (Halıcı, 1964, s. 44).

Halıcı'nın "Niyaz" şiirinde ise tecellinin salikin gayret etmesiyle ve nefsin yedi makamını geçmesi şartıyla görüleceği verilmiştir. Eğer salik nefsini öldürebilirse her yerde ve her şeyde Yaratıcı'nın tecellisini görebileceği vurgusu yapılmıştır:

“Baksan haktır, hangi yana

Bir nazar k1l, yana yana.

Kolayca görünmez mânâ

Yedi tepeyi aşmadan." (Halıcı, 1964, s. 56).

"Beni Sen Kıl" mensur şiirinde ise tecelli, daha derin bir hâl ile ele alınmaktadır. Burada derviş; Allah Teala'ya aşkıyla, feyzi ve muhabbetiyle yaklaşırken Cenab-1 Hakk'a giderek O'nda O'nunla bir olarak ve Allah Teala'nın oluru ile dervişin $O$ olması şeklinde verilmiştir: 
“...Senin tellerinde iki elimde iki kalem seni şekillerken, zor adımlarla seni parsellerken, milim milim heybetine, güzelliğine yelken açarken (işte tam o zaman ben sence sencileyin olurken) beyaz güvercinleri ak kâğıtlardan koyverme üzerime üzerime!." (Halıcı, 1998, s. 41).

Şiirin özellikle "seni şekillerken" kısmı, kulun nefsine Cenab-1 Hakk'ı, O'nun emirlerini, isteklerini, muhabbetini işlemesi olarak değerlendirilmelidir. "Gel” adlı şiirin

"Sır sendedir, ben kendimde değilsem,

Has bahçene bir dal gibi eğilsem.

Bir hangi kubbede yeşerdin, bilsem,

Ey varlıkta tecelli eden şey, gel!"' (Halıcı, 2000, s. 355).

dizelerinin ilk mısrasında Halıcı, dervişteki hâlin Yaratıcı'dan olduğunu belirtmiş, ikinci mısrada Allah Teala yolunda ilerleme arzusunu vermiştir. Üçüncü ve dördüncü mısralarda ise Cenab-1 Hakk'ın cemadatta tecellisini vurgulamıştır. Şairin "Candan Öte" şirinde ise mürşidin, dervişi tasavvuf için aslolana yani muhabbetullaha çekmesi, Allah Teala'nın kulunu kendine bağlaması işlenmiştir. Ayrıca dervişin veya kulun gözünden dünyanın uzaklaşması yani değerini kaybetmesi kişiyi mürşidin istediği bir derviş, Yaratıcı'nın ise istediği salih bir kul hâline getirmiştir. Bu mertebeye ulaştığı görülen derviş ya da salih kul artık Allah Teala'nın cemadatta tecellisini görmekte, dünya âdeta Cenab-1 Hakk'ı yansıtan bir ayna olmaktadır:

"Yâr kemend atmış boynumdan

Çeker gerçek aşka beni.

Dünya çekilmiş aynımdan

Ayna kılar ışka beni..." (Halıc1, 2000, s. 362).

\section{Nefs}

Tasavvufta nefs, yedi makam olarak tarif edilmiştir. Salik, sülukunda mücadele ile bu yedi aşamayı mürşidinin yardımıyla aşma, ilk nefis derecesi olan nefs-i emmâre'den sonra nefs-i levvâme, nefs-i mülhime, nefs-i mutmeinne, nefs-i râdiye, nefs-i merdiyye ve son derece olan nefs-i kâmileye erişip irşad makamına yükselmiş olma (Yılmaz, 2019, s. 234-237) arzusundadır. Nefsi terbiye edip nefsin sekînete ermesi, dervişin manen ilerlemesine bağlıdır. Müridin görevi nefsiyle mücadele etmektir. Bu mücadeleyi başaran mürit, tasavvufi hayatında maddeten ve manen huzura ermiş demektir.

Tasavvufla ilgili edebî eserler ya da tasavvuf etkisinde kalmış herhangi bir metne bakıldığı zaman muhakkak okuyucunun karşısına nefs kavramı çıkacaktır. Bu kavram, Feyzi Halıcı şiirinde de görülmektedir. Şair, "Erzurumluyum" şiirinde Erzurumlu divan ve halk şairlerini sıralamıştır. Halıcı'nın özellikle bu kişileri seçmesi bilinçli bir tasarruftur. Bu şairlerden Nef' '̂́'nin şiiri övme, övünme ve yerme üçlüsüyle özetlenmektedir (Akkuş, 1993, s. 25). Ancak aşağıda aktarılan şiirin son dörtlüğünün tasavvuf içerikli olması bu şairlerin Halıcı tarafından özenle seçildiğini düşündürmektedir. Çünkü "Nef'î, Farsça divanında şiirini tasavvufi aşk çevresinde yoğunlaştırır. Kişiliği ilahi aşka daha yakındır" (Akkuş, 1993, s. 35). Bir başka şair ise Âşık Sümmânî'dir. Sümmânî'nin dinî tasavvufi şiirleri vardır ve bunlar daha çok nasihat özelliği taşımaktadır. Bu şiirlerinde Sümmânî'nin, Emrah'ın etkisinde kaldığı söylenebilir (Albayrak, 2001, 28). Emrah'ın şiirlerinde ise medrese 
eğitiminin de tesiriyle dinî ve tasavvufi bilgiler yer almaktadır (Alptekin, 2004, s. 80). Şiirde Erzurumlu nefsini ezmiş ve fenafillaha ermiş bir salik olarak işlenmiştir:

“Canım Nef'î söyler, içim gümrahtır,

Dilim Sümmanîdir, sözüm Emrahtır.

Yolum Hak'tır, özüm fena - fillahtır

Ben Erzurumluyum Erzurumluyum." (Halıc1, 1983, 251).

Halıcı, “Niyaz” şiirinde ise

“...

Kolayca görünmez mânâ

Yedi tepeyi aşmadan." (Halıcl, 1964, s. 56).

mısraları ile dervişin "mânâ"ya yani aslolana, Yaradan'a ulaşması için nefs derecelerini aşması gerektiğini vermektedir. Şiirin devamı olan

“Hak âşı̆̆ı bilen bilir,

Alan nasibini alır.

Gayrı muhabbet mi olur

Kul, nefsiyle barışmadan." (Halıcı, 1964, s. 56).

dizeleri de yukarıdaki mısralarla alakalıdır. Halıcı yine dervişin muhabbetullaha ermesi için nefsini Hak yoluna yönlendirmesi, onu sslah etmesi gerektiğini vurgulamaktadır. "Nefs" kavramının şiirin son dizesinde verilmesinin amac1, şairin bu tasavvuf istılahını vurgulamak istemesidir. Çünkü şiirin önceki dörtlüğünde geçen "Yedi tepeyi aşmadan." mısrası dikkate alındığında "kulun nefsiyle barışması" hususunun tasavvufi açıdan değerlendirilmesi gerektiği ve buradaki mısranın nefs mertebeleriyle ilişkili olduğu görülecektir. Nefs-i mutmeinne makamını açıklayan şu ifadeler bu mısranın bu mertebeyle alakalı olduğuna bir işarettir: "Bu nefs, Cenab-1 Hakk'ın tevfik ve inayetiyle sekînet ve yakine mazhar olarak 1ztıraplardan kurtulur" (Yılmaz, 2019, s. 235-236). Görüldüğü üzere şiirin bu mısrası bu açıklamayla örtüşmektedir. Çünkü "kulun nefsiyle barışması" huzura ermesi anlamını taşımaktadır. Ayrıca "Hak âşığı" terkibi de şiiri yorumlamak açısından dikkat çekici bir ayrıntıdır. Bu terkip, şiirin tasavvufi yönünü ortaya çıkarmakta ve kaynağını göstermektedir. Halıcı'nın "Ölüm Duvarı" adlı şiirinin son dizelerinde ise asli hayatın nefsi öldürmekle olacağı verilmekte, manen hayatta kalabilmenin sırrının ise $\mathrm{Hz}$. Mevlânâ'da olduğu büyük harflerle yazılarak vurgulanmaktadır:

“Ölmek, doğmak, bu işte, en büyük mânâ,

Sonsuz yaşamak sırrı sende, MEVLÂNA.." (Halıc1, 1964, s. 69).

Halk şiiri tarzında yazılan "Hak Aşıklarına" adlı şiirde ise Feyzi Halıcı, tasavvuf terminolojisinde önemli olan dergâh, himmet, keramet gibi ıstılahları vermekte (Âşık Fezâ̂, 1998, s. 81-82), manevi ilerleyiş için benliğin yok edilmesi, aklın bir kenara bırakılmasını ifade etmektedir. Şair, maddeten var olan dervişin varlık, benlik duygularından yani nefsinin istediklerinden vazgeçince yok olacağını, bir başka ifadeyle manen olgunlaşıp sülukunda ilerleyeceğini, bu sayede de Allah Teala ile hemhâl olacağını söylemektedir:

"Dostlar meclisine geldik oturduk, 
Topraksız tarlada darı bitirdik.

Benlik kavgasında akıl yitirdik

Varlıkta yok oldu, yolumuz bizim." (Âşık Fezâ̂, 1998, s. 82).

"Yücesin" şiirinde ise şair, bir derviş için çok önemli bir haslet hatta vazife olan tefekkürü işlemekte, müridi aydınlatan hususun aşk olduğunu vermektedir. Ayrıca şair, Cenab-1 Hak katında değerli olmanın yolunun benlik, gurur gibi nefsani duyguların terki ile meydana geleceğini ve kişinin bu nefsani marazlardan kendini soyutlamasıyla günahsız meleklerden daha yüce olacağını vurgulamaktadır. Bu husus "Biz, hakikaten insanoğlunu şan ve şeref sahibi kıldık. Onları, (çeşitli nakil vasıtaları ile) karada ve denizde taşıdık; kendilerine güzel güzel rızıklar verdik; yine onları, yarattıklarımızın birçoğundan cidden üstün kıldık" (Karaman vd., 2015, s. 273) şeklinde meali verilen İsrâ Suresi 70. ayet-i kerimeyi de çağrıştırmaktadır:

“Duy gönülce, tefekkür et, nicesin?

Aşktan uzaksan karanlık gecesin.

Terk edersen bencilliği, gururu,

Hak katında meleklerden yücesin." (Halıcı, t.y., C. [1], s. 63).

\section{Aşk, Feyz ve Muhabbet}

Aşk duygusu yaratılışı gereği insanın içinde hep varolagelmiştir. Bu duygu hemen her zamanda ve hemen her şair tarafından şiire tema olmuş, beşerî ve ilahi olarak ayrı ayrı ele alınmış bazen de bu iki farklı yaşantı birlikte verilmiştir. Bu duygu, Halıcı'nın "May Geçidi" adlı şiirinin "IV" numaralı kısmında yer alan

“Bir parça aşk, verir elbet tohuma can.” (Halıcı, 1960, s. 30).

dizesinde olduğu gibi bazen beşerî aşk verilerek bazen de Yunus Emre'nin

“Leyla Leyla derken Mevlayı buldum"1 (Hatipoğlu, 1993, s. 31).

dizesinde görüldügü gibi ilahi aşka bir vasıta olarak işlenmektedir.

Allah Teala'nın kulundan istediği O'na dua etmesidir. Furkan Suresinin 77. ayetinde bu açıkça beyan edilmiştir: "(Resulüm) De ki: (Kulluk ve) yalvarmanız olmasa, Rabbim size ne diye değer versin?.." (Karaman vd., 2015, s. 356). Bu ayette belirtildiği gibi Feyzi Halıcı'nın "Ergeç" şiirinde de kulun dua ile ısrar ederek ilahi aşkı Yaratan'dan istemesinin önemi vurgulanmaktadır:

"Sanma sevdiceğim vakit çok geç,

İşte bir 1şık geçit, durma geç!

Dile, yüce Hak'tan mutluluğu,

Aşk burcuna kavuşursun ergeç." (Halıc1, t.y., C. 2, s. 48).

Tasavvuf anlayışının mürşit vasıtasıyla salikin ilahi aşka ermesinin yolu olarak görüldüğü bilinmektedir. Bu, mürşide yaratıcllık kutsiyeti oluşturmak değil, dervişe sadece yardım eden konumu vermektir. Çünkü inananlar için Yaratıcı tektir. "Müjde" şiirinde ilahi aşk bu şekilde işlenmekte, tasavvuf yolu ile müridin onurlandırılacağ

\footnotetext{
${ }^{1} \mathrm{Bu}$ şiir, Mustafa Tatcı tarafından hazırlanmış olan "Dîvân-ı İlâhiyât" adlı eserin "Âşık Yûnus'un veya Başka Yûnuslar'ın Şiirleri" kısmında verilmektedir (bk. Yûnus Emre, 2014, s. 647-718).

SEFAD, 2021; (46): 1-22
} 
“Ferhat nasıl özlediyse Şirin'i,

Sevdiceğim durma, ara pîrini!

Olacaksın bir gün, dillere destan,

Bütün dünya okuyacak şîrini." (Halıcı, t.y., C. [1], s. 27).

Halıcl, "Konya" adlı şiirinin şu mısralarında ise zahirî sultanlarıyla bu şehrin tarihinden bahsettiği gibi Hz. Mevlânâ ile de şehrin manevi sultanını vermiş ve O'ndaki ilahi aşka da değinmiştir:

“Sen ney dilinde uhrevî,

Mevlânanın aşk alevi.

Dile getir Keyhüsrevi

Nağmeler sun, Keykubattan." (Halıcı, 1952, s. 23).

Hz. Peygamber'e olan itaat ve sevgi İslam'ın bir gereğidir. Bu gerek, A'râf Suresi 158. ayette itaat şeklinde emrolunmuştur: “De ki: Ey insanlar! Gerçekten ben sizin hepinize, göklerin ve yerin sahibi olan Allah'ın elçisiyim. Ondan başka Tanrı yoktur, O diriltir ve öldürür. Öyle ise Allah'a ve ümmi Peygamber olan Resulüne -ki O, Allah'a ve Onun sözlerine inanır- iman edin ve O'na uyun ki doğru yolu bulasınız" (Karaman vd., 2015, s. 159). Şu hadis-i şerifte ise Hz. Peygamber'e muhabbet beslenilmesi gerektiği verilmiştir: "Sizden biriniz beni annesinden, babasından, çoluk çocuğundan ve bütün insanlardan daha çok sevmedikçe iman etmiş olamaz" (Buhârî, 1422/2001, İman 8). Akait bakımından İslam'ın istediği şeylerin mutasavvıflarca da tasdiği gerekmektedir. Tasavvuftaki tasdik muhabbetle iç içedir. Halıcı'nın "Her Şey" adlı şiirinde ise "Sen olmasaydın, sen olmasaydın felekleri yaratmazdım" (el-Aclûnî, 1351, 164) hadis-i şerifine telmih yapılarak Hz. Peygamber'e olan muhabbet vurgulanarak aşk verilmiştir:

"Şu dağ, beyaz beyaz, şu su mavi mavi,

Aşkın şu bitmek bilmeyen alevi.

Yolların sonunda ne varsa uhrevî

Her şey yüzün suyu hürmetinedir." (Halıcı, 1964, s. 37).

\section{Varlık-Yokluk}

"Ölmeden evvel ölünüz" (el- Aclûnî, 1351, 29) hadis-i şerifi varlık âleminde kulun nefsini öldürerek dünyevi haz ve heveslerin yokluğuyla manen var olmasını açılamaktadır. Feyzi Halıcı şiirinde de varlık-yokluk kavramları belirgin bir şekilde verilmektedir. Bunlardan biri de "Yokluk - Varlık" adlı dörtlüktür:

"Can güzel, cana biçilen pahâ güzel,

Hasret hasret kavuşmak Allaha, güzel..

Gerçek, yüce varlığınla yok-olduğum;

Ne yokluk ki bu, varlıktan daha güzel." (Halıcl, 1964, s. 6).

Bu dörtlükte Halıcı; hasreti yokluk, vuslatı varlık olarak görmektedir. Ayrıca şair, zahiren Cenab-ı Hakk'ın varlığının görünür olmamasına rağmen Allah Teala'nın insanda, hayvanda, cemadatta kısaca her şeyde görünülürlüğünü anlayabilme mertebesine ulaşmış yani yokluk içinde varlığa erişmiş biri olarak kendisini vermektedir. Halıcı, "Sevgi Şehidi" 
adlı mensur şiirinde de varlık-yokluk kavramlarına, gül ve bülbül mazmunlarını kullanarak değinmektedir:

"Yokluk içinde var olmak, bülbülün endişesi." (Halıcı, 1998, s. 41).

Bu mısra; âşık-maşuk, mürit-mürşit, kul-Allah arasındaki ilişkiyi göstermektedir. Burada sevenin sevdiğinde kaybolma arzusu işlenmektedir.

Dünya zahirî varlık yeridir. Manevi ilerleme için dervişin şehvani arzularına gem vurması gerekmektedir. Bu isteklere boyun eğmemesi var olan şehevi unsurların yok olması anlamına gelir. Varlık içinde yokluk yaşama hâli, süluk için ya da genelleştirilme yapılırsa kul için gereklidir. Varlık-yokluk bahsi şairin “Yok $\mathrm{Ol}^{\prime}$ dörtlüğünde de geçmektedir:

"Sevdadan öte hasret, vuslattan öte yol,

Bengi-1şık gönülleri çeker nihayete, yol.

Varlık-sedâsına bir-yol kulak verme, ey can

Candan öte ateş dolu bir kubbede yok ol..." (Halıc1, 2000, s. 347).

Bu şiirde bazı sözcükler vardır ki dikkat edilmesi gerekmektedir. Bunlar cinas yapılan "yol", "ateş" ve "kubbe" sözcükleridir. "Yol" ile tasavvufun, "kubbe" ile dergâhın ve "ateş" ile manevi aşkın verildiği söylenebilir.

\section{SONUÇ}

Tasavvuf, birçok modern Türk şairi tarafından işlenmiş bir izlektir. Bu izleğin şiirlerinde belirgin bir şekilde yer aldığı şairlerden biri de halk şiiri tarzında da şiirleri bulunan ve bu şiirlerde de tasavvufi izleğe yer veren Âşık Fezaî mahlaslı Feyzi Halıcı'dır. Şair, herhangi bir tarikata müntesip olmasa da birçok şiirinde Mevleviliğin etkisinde kalarak tasavvuf içerikli şiir örnekleri vermektedir. Feyzi Halıcı şiirinin toplu okunması onun hem modern tarzda hem de halk şiiri tarzında şiirler yazdığını göstermektedir. Şair, "Yaylaya Bir Gelin Geldi" adlı şiir kitabını Âşık Fezaî mahlasıyla yani halk ozanı kimliğiyle yazmıştır. Bu eser bile onun âşık tarzı şiirin 20. yüzyıl temsilcilerinden biri olduğunu göstermesi bakımından yeterlidir. Fakat şairin bu eseri haricinde bu çalışmada çeşitli örneklerle verilen on iki ayrı kitabı daha vardır. Bu kitaplarda şair çeşitli nazım birimlerini kullanarak şiirler yazmıştır. Bu eserler Halıcı'nın âşık kimliğinin yanında modern bir şair de olduğunu göstermekte ve Halıcı, çağdaş tarzın çeşitli biçimlerini de şiirinde kullanmaktadır. Şair bunları yaparak tasavvufu her bir tarz içine yerleştirmiştir. Ancak Feyzi Halıcı şiirinin genel olarak taranması onun salt tasavvufu izlek olarak ele aldığı sonucunu vermemektedir. Çünkü şiirinde zahiri sevgiliye olan aşk da vardır. Bu husus şairin "Başlangıç" adlı eserinde Mevlevi postnişin Şeyh Galip'in beşerî aşkının verilmesiyle görülmektedir. Bunun yanında "Konya" adlı şiirinde -manevi aşk haricinde ama bu aşkla birlikte- Halıcı'nın bazı hükümdarları belirterek bu şehrin tarihine de yer vermesi, onun tasavvuf dışında da bazı hususlara değindiğini göstermektedir. Fakat Halıcı şiirinde ayrı bir yeri olan ve belirgin bir şekilde görülen tasavvufun yoğun bir şekilde şiirlerine sirayeti ise yadsınamaz bir gerçektir.

$\mathrm{Bu}$ çalışmada tasavvufi terminoloji dikkate alınarak Feyzi Halıcı'nın şiiri incelenmiştir. Tasavvuf ıstılahı geniş bir alanı kapsamaktadır. Şairin tamamen bu terimleri şiirine yansıtması bir güçlüğü ortaya çıkaracaktır. Çünkü bu bir birikim gerektirmektedir. $\mathrm{Bu}$ ise -kesin olmasa da- daha çok intisabı olan ve kitabi olarak tasavvuf bilgisine sahip ve güçlü şairler tarafından yazılabileceği yargısına götürmektedir. Feyzi Halıcı şiiri bu 
tasavvufi sstılahlar çerçevesinde değerlendirildiği zaman makalede ele alınan bütün eserlerin teker teker incelendiğini ve çalışmadaki başlıklarla verilen terimlerin Halıcı şirinde görüldüğünü belirtmek gerekir. Şairin şiirleri bu terminoloji etrafında yoğunlaşmıştır. Bu bağlamda şiirlerde Hz. Mevlânâ, Yunus Emre, Ahmed Yesevî ve Galata Mevlevihanesi postnişini Şeyh Galip gibi tasavvuf büyükleri yer almıştır. Ayrıca şeyhlik makamı olan mürşitlik; dervişlik makamı olan müritlik kavramı ele alınmakta, Mevleviliğe özgü zikir yani sema verilmekte, ney ve kudüm gibi Mevlevi enstrümanlar işlenmektedir. Bunun yanında tecelli kavramı şiire katılmakta, nefs makamları vurgulanmaktadır. Bu hususların yanı sıra tasavvuf için elzem bir kavram olan aşk, feyz ve muhabbet hâli görülmekte ve son olarak da varlık-yokluk kavramlarına değinilmektedir. Bu hususlar şairin ele alınan şiirlerinin tasavvufi olduğunu göstermektedir. Bu makalede belirtilen başlıklar içinde örnek verilen ve tasavvufi olarak yorumlanabilecek şiirler tahlil yapılarak incelenmiştir. Feyzi Halıcı şiiri için şunu da söylemek gerekir ki şairde Melami bir tavırdan ziyade onda teslim olmuş ve mutmain bir kalp ile bağlanmış bir dervişin hâli sezilmektedir. Mürşit ise Hz. Mevlânâ'dır. Şair, müntesip olmasa da bu duyguyu içselleştirebilmiştir. Kültüre bağlı olarak, yaşanılan şehre ait olan değerler o şehrin mekinleri tarafından kıymetli addedilir. Bu açıdan düşünüldüğü zaman Halıcı'nın Hz. Mevlânâ'ya olan muhabbeti memleketinin tasavvuf büyüğüne olan hürmeti olarak da değerlendirilebilir. Fakat bu kesin bir dille söylenebilecek bir yargı değildir. Çünkü şiirlerinde Hz. Mevlânâ'ya olan muhabbetinde Halıcı'nın samimi bir derviş edasında olduğu görülmektedir.

Tasavvufta teslimiyet ve samimiyet çok önemli değerler olduğu için yazılan eserlerde de bu duyguların yansıtıldığını görmek bir kriter olarak sayılabilir. Bu, Feyzi Halıcı'nın/Âşık Fezaî'nin tasavvuf içerikli şiirlerinde vardır. Fakat müntesip olan bir şairin dergâh deneyiminin ve mürşit terbiyesinin de etkisiyle şiirlerinde verdiği yaşantısal duyguyu yani hâl duygusunu Halıcı'nın intisabının olmamasından dolayı şiirine yansıtamaması, bu bağlamda şairde bir eksikliğin oluşmasına sebep olmaktadır. Neticede Feyzi Halıcı şiiri tasavvufi açıdan sıradanın dışına çıkmış bir şiir olmayıp muhabbetin, özellikle Mevleviliğe ve Hz. Mevlânâ'ya olan sevgi ve bağlılığın ürünüdür.

\section{SUMMARY}

Sufism, as a wise institution, is a religious foundation with followers around the world. Sects that have many branches such as Kadiri, Nakşi, Celveti, Halveti, Uşşaki, Rufai, Bektaşi and Mevlevi are a social belief system. Sufism is also discussed in the poem fed by the society. Sufism was treated by poets in many periods of Turkish poetry. This institution was also addressed by many poets of modern Turkish poetry. One of these poets is Feyzi Halıcı. Sufism, which is treated by Sufi poets, has also been handled by poets who are not involved, but have somehow been influenced by Sufism or have traces of Sufism. Feyzi Halıc is also one of the poets who are not affiliated with any sect, but who clearly shows the influence of the Mevleviyeh in his poems. As a result of our investigations, it was not seen that the poet was affiliated with any sect, and also as a result of our interview with the poet's sister Nevin Halıc1, Nevin Halıcı stated that her brother Feyzi Halıcı was not affiliated but the poet had a deep knowledge of Sufism. The interest and influence of Mevleviyeh is also seen in Halıci's poems. This effect has been tried to be shown in nine titles related to Sufism as Sufism elders, murshid, disciples, dhikr, Mevlevi instruments, manifestation, nafs, love, and presence and absence. In the title of Sufism elders, especially Hz. Mevlânâ was treated and seen as an occasion in the poem "Sitem". As seen in the poem "Hak Aşılarına" besides 
Hz. Mevlânâ, in the tetralogy Yunus Emre ,"Pîr-i Turkistan", Ahmed Yesevî, as given in the poem "Başlangıç", in the III. Selim, Beyhan Sultan, and Seyh Galip, one of the Divan poets of 18th century, were depicted. In addition to Sheikh Galip's poetry, the fact that he was the Sheikh of the Galata Mevlevi lodge is the reason why Sheikh Galip is treated under the title of Sufism elders. Murshid is seen as a spiritual educator for the spiritual advancement of the dervish in Sufism. This issue is one of the elements treated in Halıci's poetry. There is one thing that the dervish should pay attention to, which is his complete devotion to his master. Halıc has exemplified this situation in his poem. Another title is the disciple. A complete devotion of the disciple to his master is required. This is necessary for the soundness of the spiritual journey. In the disciple mention, Halıc treated both spiritual love and murshid's love to it. In addition, the conversation between Hz. Mevlânâ and Şems-i Tebrizi was also treated under this title. The expression "... the first Mevlevi" in the poem "İstanbul CaddesiGünaydın" was treated in the mention of the disciple, and with this definition the poet can refer to Mevlânâ as well as Şems-i Tebrizi. In his poem, "Dişe Diş", Halıcı is happy as his path is the one Mevlânâ's. The title of dhikr is another sufistic term mentioned by Halıcı. Dhikr is a form of worship peculiar to sects. In some sects, dhikr can be made silently, in some vocal, in others standing and turning. In Mevleviyeh, dhikr is in the form of sema. In this title, Mevlevi dhikr was treated more. In "Struga Şiirleri III", with the "Gel" call attributed to Mevlânâ, Halıcı mentioned Mevlevi dhikr. In the verse of "Aşk içre döne dolana" in the poem "Gelmedin", sema was mentioned. In addition, in the poetry of Halıc1, the Mevlevi dhikr dress, "tennure", is mentioned frequently. Under the title of Mevlevi instruments, instruments such as ney and kudum were considered as a spiritual occasion. In the poem of "Başlangıç" the holiness of ney is explained by making a reference to the first couplet of Mevlânâ's Mesnevi. Manifestation is one of the sufi term that are widely discussed in Sufistic poems. Feyzi Halic also used this term in his poetry. In the poem "Niyaz" when the effort of dervish and seven levels of nafs are mentioned, it is a warning that God can see manifesatation in everywhere. The manifestation of God on objects is emphasized in the poem of the poet "Gel". Nafs is an enemy that a dervish must fight in the direction of his travels in Sufism. The disciple uses his efforts to destroy this enemy. By emphasizing that his "essence is a mystery" in the poem "Erzurumluyum", Halıc1 announces a holy disciple to reader. In the poem "Niyaz" in the line "Yedi tepeyi aşmadan" the levels of dervish's nafs and the necessity of passing these stages were emphasized. In the poem "Ölüm Duvarı" it is stated that essential life will come true by killing nafs. In the poem "Hak Aşıklarına", the necessity of the disciple to leave the mind aside and destroy his ego is mentioned. In the quatrain of "Yücesin", it is stated that spiritual progress will come true by leaving selfishness.

The mention of "Love" is also important in reading Feyzi Halıci's poem in a mystical context. Love is the divine love of the disciple to God. In the poem "Ergeç" Halıcı mentioned the creature to insist on prayer and ask love from God. In the poem "Konya", the divine love of Hz. Mevlânâ is mentioned. In the poem "Her Şey" by attributing the event "If you weren't, I wouldn't have created universe.", Halıc1 treated the term of love. The last title in Halıc poetry is the notions of "Presence-Absence". In the poet's quatrain "Varlık- Yokluk", he emphasized that the person will exist spiritually by destroying worldly pleasures, ambitions and desires. The poet has stated that the real presence is formed by disappearing in God. In his prose poem "Sevgi Şehidi", the poet tried to give the notions of presenceabsence by using rose-nightingale poetic. 
Makale Bilgileri

Etik Kurul Kararı:

Katılımo Rizası:

Mali Destek:

Çıkar Çatışması:

Telif Haklart:

Article Information

EthicsCommitteeApproval: InformedConsent:

Financial Support:

\section{Conflict of Interest:}

Copyrights:
Etik Kurul Kararından muaftır.

Katılımcı yoktur.

Çalışma için herhangi bir kurum ve projeden mali destek alınmamıştır.

Çalışmada kişiler ve kurumlar arası çıar çatışması bulunmamaktadir.

Telif hakkına sebep olacak bir materyal kullanılmamıştır.

Exempt from the Ethics Committee Approval.

No participant.

The study received no financial support from any institution or project.

No conflict of interest.

No material subject to copyright is included. 


\section{KAYNAKÇA}

Akkuş, M. (1993). Nef'î dîvânı. Ankara: Akçağ Yayınları.

Albayrak, N. (2001). Sümmânî. İstanbul: Timaş Yayınları.

Alptekin, A. B. (2004). Palandöken'in zirvesindeki âşık Erzurumlu Emrah. Ankara: Akçağ Yayınları.

Aresteh, A. R. (2007). Aşkta ve yaratıcılıkta yeniden doğuş-Mevlânâ Celâleddîn Rûmî'nin kişilik çözümlemesi (3. bs.). (B. Demirkol \& İ. Özdemir, Çev.). Ankara: Kitâbiyât.

Âşık Fezaî. (1998). Yaylaya bir gelin geldi-şiirler. Ankara: Aşık Ofset.

Ayvazoğlu, B. (1999). Kuğunun son şarkısı. İstanbul: Ötüken Neşriyat.

Buhârî, Muhammed b. İsmâîl. (1422/2001). el-câmiu's-sahîh (Muhammed Züheyr b. Nâsıru'n-Nâsır, Thk.). Beyrut: Dâru Tavki'n-Necât.

Çelebi, A. H. (1957). Mevlânâ ve Mevlevilik. İstanbul: Nurgök Matbaası.

el-Aclûnî, İsmail b. Muhammed. (1351). Keşfu'1-hafâ ve müzîlü'l-ilbâs ammeştehara mine'1ehâdîs alâ elsineti'n-nâs II. Beyrut: Dâru İhyâi't-Türâsi'l-Arabî.

Gölpınarlı, A. (2004). Tasavvuf (3. bs.). İstanbul: Milenyum Yayınları.

Gönen, S. (2016). Âşıkların babası Feyzi Halıcı ve hayatı. A. B. Alptekin (Haz.), Feyzi Halıcı ve yirminci yüzyıl âşıkları üzerine araştırmalar I içinde (s. 11-21). Ankara: Akçağ Yayınlar1.

Halıcı, F. (1952). Masmavi-şiirler. İstanbul: Hisar Yayını.

Halıcı, F. (1956). İstanbul caddesi-şiirler. İstanbul: Şehir Matbaası.

Halıcı, F. (1960). Günaydın-şiirler. İstanbul: Büyük Kervan Matbaası.

Halıc1, F. (1964). Dinle neyden-şiirler (2. bs). Ankara: Mars Matbaası.

Halıcı, F. (1966). Gecenin bir yerinde iki ceylân. Ankara: Mars Matbaası.

Halıcı, F. (1967). Selçukya'da aşk-şiirler. Ankara: Mars Matbaası.

Halıcı, F. (1981). Mevlâna ve Mesnevî. F. Halıcı (Haz.), Mevlâna sevgisi içinde (s. 40-44). Konya: Konya Turizm Derneği Yayınları.

Halıcı, F. (1983). Yaşama sevinci-şiirler. Ankara: Güven Matbaası.

Halıcı, F. (1998). Selçukya güzellemesi-şiirce. Ankara: Aşık Ofset.

Halıcı, F. (2000). Seçme şiirler. Ankara: T.C. Kültür Bakanlığı Yayınları.

Halıcı, F. (2005). Şiirler-dörtlemeler. y.y: y.y.

Halıcı, F. (t.y.). Dörtleme'ler-şiirler (C. [1]). Ankara: Güven Matbaası.

Halıcı, F. (t.y.). Dörtleme'ler-şiirler (C. 2). y.y: y.y.

Hatipoğlu, A. (1993). Besteleriyle Yunus Emre ilâhîleri. Ankara: Türkiye Diyanet Vakfı Yayınları.

Kara, M. (2015). Din hayat sanat açısından tekkeler ve zâviyeler (6. bs.). İstanbul: Dergâh Yayınları.

Karaman H., Özek A., Dönmez İ. K., Çağrıcı M., Gümüş S. \& Turgut A. (2015). Kur'ân-1 Kerîm açılamalı meâli (3. bs.). Ankara: Türkiye Diyanet Vakfı Yayınları.

Kılıç, M. E. (2013). Tasavvufa giriş (4. bs.). İstanbul: Sufi Kitap.

SEFAD, 2021; (46): 1-22 
Masala, A. (1987). Feyzi Halıcı'nın şiirlerinden seçmeler (A. Masala, Çev.). Ankara: Güven Matbaası.

Mazıoğlu, H. (1981). Anadolu'da Türk edebiyatının başlamasında ve gelişmesinde Mevlânâ'nın yeri ve etkisi. F. Halıcı (Haz.), Mevlâna sevgisi içinde (s. 30-39). Konya: Konya Turizm Derneği Yayınları.

Mevlânâ. (2013). Mesnevî-tam metin (13. bs.). (A. Karaismailoğlu, Çev.). Ankara: Akçağ Yayınları.

Necatigil, B. (2007). Edebiyatımızda isimler sözlü̆ğ̈̈ (24. b.s). İstanbul: Varlık Yayınları.

Ocak, A. Y. (2016). Türkler, Türkiye ve İslâm-yaklaşım, yöntem ve yorum denemeleri (14. bs.). İstanbul: İletişim Yayınları.

Şafak, Y. (2009). Mevlânâ'ya atfedilen "yine gel..." rubâisine dair. Tasavvuf İlmî ve Akademik Araştırma Dergisi, 24 (2), 75-80. Erişim adresi: http://yakupsafak.com/yazilar/46.pdf. Erişim tarihi: 03.03.2021.

Uludağ, S. (2005). Tasavvuf terimleri sözlüğ ü (2. bs.). İstanbul: Kabalcı Yayınevi.

Uludağ, S. (2014). Tasavvuf ve tenkit. İstanbul: Dergâh Yayınları.

Uludağ, S. (2017). İslâm ve musiki (2. bs.). İstanbul: Dergâh Yayınları.

Ülken, H. Z. (2017). Anadolu kültürü üzerine makaleler (2. bs.). G. Ülken (Haz.). Ankara: Doğu Batı Yayınları.

Yılmaz, H. K. (2019). Ana hatlarıla tasavvuf ve tarîkatlar (29. bs.). İstanbul: Ensar Neşriyat.

Yûnus Emre. (2014). Dîvân-ı ilâhiyât (3. bs.). M. Tatcı ( Haz.). İstanbul: H Yayınları. 